\title{
Response of Summer Cowpea to Growth, Yield and Water Use Efficiency under different Irrigation and Nutrient Management in Lower Indo-Gangetic Plains
}

\author{
Anirban Bhowmik ${ }^{1 *}$, Subam Khawas ${ }^{1}$, Gopal Dutta ${ }^{2}$, Ratneswar Ray ${ }^{1}$ \\ and Sanmoy Kr. Patra ${ }^{3}$
}

${ }^{1}$ Departmentof Soil and Water Conservation, ${ }^{2}$ Department of Agricultural Meteorology and Physics, ${ }^{3}$ Department of Agricultural Chemistry and Soil Science, Bidhan Chandra Krishi Viswavidyalaya, Mohanpur 741 252, West Bengal, India

*Corresponding author

\begin{tabular}{|c|c|}
\hline & A B S T R A C T \\
\hline Keywords & \multirow{4}{*}{$\begin{array}{l}\text { A field experiment was conducted during } 2018 \text { at the Instructional Farm, Bidhan Chandra } \\
\text { Krishi Viswavidyalaya, Jaguli, Nadia to study the effects of three irrigation regimes (CPE } \\
60 \mathrm{~mm} \text {, CPE } 50 \mathrm{~mm} \text { and CPE } 40 \mathrm{~mm} \text { ) and five nutrition (control, FYM @ } 2.5 \mathrm{t} / \mathrm{ha} \text {, } \\
\text { cowdung @ } 10 \mathrm{t} / \mathrm{ha} \text {, poultry manure @ } 2.0 \text { t/ha and RDF) on summer cowpea. The results } \\
\text { showed that under plenty water supply condition, scheduling of irrigation at CPE } 40 \\
\text { accompanied with } 100 \% \text { recommended dose of fertilizers }(12.5: 25: 12.5 \mathrm{~kg} / \mathrm{ha} \text { of } \mathrm{N}, \mathrm{P} \text { and } \\
\mathrm{K} \text {, respectively) as basal was found to be the best treatment combination for obtaining } \\
\text { maximum growth, yield components, pod and seed yield and moderate crop water use } \\
\text { efficiency. Under limited or water constraint, deficit irrigation schedule at CPE } 50 \text { or CPE } \\
60 \text { in association with } 100 \% \text { RDF was the alternative option for achieving relatively higher } \\
\text { pod and seed yield and higher to maximum crop water use efficiency. The seasonal yield } \\
\text { response factor for cowpea was found to be } 4.64 \text {. }\end{array}$} \\
\hline $\begin{array}{l}\text { Irrigation, Nutrient, } \\
\text { pod and Seed yield, } \\
\text { Crop water use } \\
\text { efficiency, Cowpea }\end{array}$ & \\
\hline Article Info & \\
\hline $\begin{array}{l}\text { Accepted: } \\
10 \text { July } 2020 \\
\text { Available Online: } \\
10 \text { August } 2020\end{array}$ & \\
\hline
\end{tabular}

\section{Introduction}

Cowpea (Vign aunguiculta L. Walp) is one of the most important food legume and nutritional security crops broadly cultivated in semi-arid regions of the world. It is also a versatile crop well adapted to a diverse soil and climatic conditions of the humid tropics and sub tropical zones. It is primarily cultivated as a kharif and summer season vegetable pulse crop in India. Being short duration, it is best accommodated in the
Indian farming system as a main pulse crop, catch crop, cover crop, fodder crop, green manure crop and intercrop under dry land farming as well as irrigated condition. Cowpea is known for its nutritional value for human diet as well as for livestock feed and a source of income generation for resource poor farmers (Sheahan, 2012) ${ }^{(15)}$. It is a major source of carbohydrates (63\%) and protein (25\%) with low fat content (1.5\%) and rich in vitamin $\mathrm{A}$ and $\mathrm{C}$, iron, phosphorus, calcium and amino acids like tryptophan and lysine 
(Arul Prakasham et al., 2019) ${ }^{(4)}$. The crop has the excellent ability to fix atmospheric nitrogen by root nodules to improve the soil fertility, check soil erosion by deep tap root system and add high amount of organic matter likely to be beneficial for the succeeding crop as well as soil health sustenance (Namakkaet al., 2017) ${ }^{(11)}$. In Indian states, it is mostly produced as a minor pulse crop in arid and semi-arid tracts of Rajasthan, Karnataka, Kerala, Tamil Nadu, Maharashtra and Gujarat and in some pockets areas of Punjab, Haryana, Delhi, West Uttar Pradesh and Rajasthan.

The crop is mainly grown in summer season under rainfed condition. But due to climatic aberrations there was erratic and uneven distribution of rainfall and the crop suffered several stages of soil moisture stress resulting in low productivity or even crop failure. The other reasons for the poor yield are inhabitation of the crop on marginal and submarginal land, inadequate or low fertilizer application and no irrigation at critical growth stages during hot summer months. Among the various factors of production, adequate soil moisture availability can lead to greater yield. The crop is susceptible to water stress especially at flowering and pod filling stages and markedly inhibits root hair, nodule growth and biological nitrogen fixation (Onuh and Donald, 2009; Aboamera, 2010) ${ }^{(13,2)}$. Water stress affects the whole process of growth of all organs, metabolism and photosynthesis rate of plant resulting into low production (Zimmermann et al., 1988) (20). Climatological approach based on the cumulative pan evaporation (CPE) is widely practiced as a method of irrigation scheduling as this concept accommodates the entire weather parameters in given soil-water-plant continuum and has higher degree of adaptability at the farmers' level. The crop is responsive to the application of organic and chemical nutrients (Singh et al., 2011a; Daramyet al., 2016; Chemutai et al., 2018) ${ }^{(17,}$
7, 6). Judicious nutrition management under water stress condition can help the plant enduring various stresses (Abedi et al., $2011)^{(1)}$. The locally available low-cost organic manures like farmyard manure, cattle manure and poultry manure can increase the yield and improve the soil physical conditions in addition to supplying the plant nutrients (Smaling et al., 1993) ${ }^{(18)}$.

In the lower Indo-Gangetic plains, cowpea is a promising and remunerative crop grown successfully during pre-kharif or summer season in upland and medium land. However, the higher productivity of this crop is limited mainly by the inappropriate irrigation and nutrient management practices. The conventional surface flooding method of irrigation commonly followed by the farmers in this region is expensive and inefficient since it causes high water and nutrients losses in deep percolation. Keeping this in view, the present study was contemplated with the objective of examining the effect of irrigation scheduling on growth, yield and yield variables and water use efficiency of cowpea.

\section{Materials and Methods}

The field experiment was conducted in summer season on cowpea during 2018 at the Instructional Farm, Bidhan Chandra Krishi Viswavidyalaya, Jaguli, Nadia encompassing the New Alluvial Zone under lower indoGangetic plains region of West Bengal. The site is geographically located at $22.93^{\circ} \mathrm{N}$ latitude and $88.53{ }^{\circ} \mathrm{E}$ longitude with an average altitude of $9.75 \mathrm{~m}$ above MSL. The experimental soil is sandy clay loam in texture and medium in soil fertility with good drainage and water transmission characteristics. The physical, hydro-physical and chemical properties of the soil are furnished in Tables 1 and2. The climatological parameters during the cropping period are illustrated in Figure 1. The treatments consisted of three irrigation 
regimes (CPE $60 \mathrm{~mm}$, CPE $50 \mathrm{~mm}$ and CPE $40 \mathrm{~mm}$ ) allotted in main plots and five nutrient management (control, FYM @ 2.5 t/ha, cowdung@10 t/ha, poultry manure @ $2.0 \mathrm{t} / \mathrm{ha}$ and RDF) in sub-plots were laid out in a split-plot design with three replications. Each treatment combination was assigned randomly to the experimental units within a block. The net plot size for each experimental unit was $3 \mathrm{~m} \times 3 \mathrm{~m}$. The entire recommended dose of fertilizers $(12.5: 25: 12.5 \mathrm{~kg} / \mathrm{ha}$ of $\mathrm{N}, \mathrm{P}$ and $\mathrm{K}$ through urea, single superphosphate and muriate of potash, respectively) was applied uniformly as basal to the whole plot in the holes dibbled earlier at a spacing of 30 $\mathrm{cm} \times 20 \mathrm{~cm}$. The fertilizers were mixed thoroughly and placed at $3-4 \mathrm{~cm}$ below the seed to avoid the direct contact of seed with fertilizers. The calculated amount of organic manure was incorporated in the holes of the selected treatments and mixed meticulously with the soil. After manuring and fertilization, two to three cowpea (cv. Rohan 1086) seeds were sown on 20.03.2018 in the holes dibbled at about $5 \mathrm{~cm}$ depth and covered with the soil to protect the germinating seeds from bird damage. Thinning was done two weeks later to maintain one plant per hole. The standard agronomic and plant protection measures were followed uniformly. Five plants from the centre of each plot were randomly selected for recording the growth and yield parameters at maturity. Cowpea was harvested manually in several pickings when the pods were fully matured. The green pods from each plot was recorded and exposed to sun drying for 8-10 days, then threshed, cleaned, sun-dried till constant weight obtained and finally the plot wise seed yield was recorded within the period 18.5.2018 to 06.06.2018.

Climatological based different irrigation scheduling was imposed in furrow in the selected plots. Daily evaporation data were recorded from a standard US Weather Bureau Class A Pan installed inside the experimental site. About 1, 2 and 3 number of irrigation at $50 \mathrm{~mm}$ depth each was adopted in irrigation scheduling of cumulative pan evaporation (CPE) at 60, 50 and $40 \mathrm{~mm}$, respectively. Irrigations were applied when CPE reached the desired level and the quantity of water applied was measured with the help of Parshall flume.

Seasonal crop water use or actual crop evapotranspiration (ETa) during the growing period (sowing to harvest) from the cowpea field was computed using the onedimensional soil water balance equation (Simseket al., 2005) ${ }^{(16)}$ as,

$\mathrm{ETa}=\mathrm{I}+\mathrm{P} \pm \Delta \mathrm{SW}-\mathrm{Dp}+\mathrm{Wg}-\mathrm{Rf}$

where, I is the amount of irrigation water applied $(\mathrm{mm}), \mathrm{P}$ is the precipitation $(\mathrm{mm})$, $\pm \Delta \mathrm{SW}$ is the change in soil water storage in the $0-45 \mathrm{~cm}$ depth soil profile between sowing and harvest $(\mathrm{mm}), \mathrm{Dp}$ is the deep percolation $(\mathrm{mm}), \mathrm{Wg}$ is the amount of water used by crop through capillary rise from groundwater $(\mathrm{mm})$, and $\mathrm{Rf}$ is the amount of runoff $(\mathrm{mm})$. The runoff (Rf) and deep percolation (Dp) were assumed to be negligible as the amount of irrigation water applied was managed carefully to prevent over irrigation or runoff.

The capillary rise from groundwater $(\mathrm{Wg})$ was assumed to be negligible as depth of groundwater table was $10-12 \mathrm{~m}$ below ground level. The amount of effective rainfall $(\mathrm{Re})$ was calculated by deducting deep percolation (Dp) from precipitation $(\mathrm{P})$. Thus, ETa $=\mathrm{I}+$ $\mathrm{Re} \pm \Delta \mathrm{SW}$.

The crop water use efficiency (CWUE) is the seed yield per unit of water used and calculated as, CWUE $=$ Y $/$ ETa $(\mathrm{kg} / \mathrm{ha}-\mathrm{mm})$

Where, $\mathrm{Y}=$ dry seed yield $(\mathrm{kg} / \mathrm{ha})$ and $\mathrm{ETa}=$ actual crop evapotranspiration ( $\mathrm{mm}$ ) 
The response of seed yield to water use was quantified through the yield response factor (Ky) and determined by mathematical model (Doorenbos and Kassam, 1980) ${ }^{(8)}$. The growth, yield variables and pod and seed yield data obtained for different treatments were subjected to analysis of variance and statistical significance between means of individual treatments was compared using the least significant difference (LSD) test at $p$ $<0.05$ (Gomez and Gomez, 1984) ${ }^{(10)}$.

\section{Results and Discussion}

\section{Growth and yield components}

The growth and yield components of cowpea which considered the indicator of economic yield were significantly influenced by different irrigation regimes and nutrient management for the period (Table 3 ). The tallest plant $(77.38 \mathrm{~cm})$, highest number of nodules per plant (37.08), number of branches per plant (5.77), number of pods per plant (10.61), number of seeds per pod (13.48), maximum pod length $(18.17 \mathrm{~cm})$ and 1000 seed weight $(67.62 \mathrm{~g})$ were obtained with irrigation schedule at CPE $40\left(\mathrm{I}_{3}\right)$ which were superior over irrigation schedule at CPE 50 $\left(\mathrm{I}_{2}\right)$ and CPE $60\left(\mathrm{I}_{1}\right)$ except pod length and 1000-seed weight where $I_{3}$ and $I_{2}$ were statistically on par with each other. Higher deficit irrigation schedule at CPE $60\left(\mathrm{I}_{1}\right)$, on the other hand, displayed significantly the shortest plant height $(72.27 \mathrm{~cm})$, lowest number of nodules per plant (32.87), number of branches per plant (3.54), number of pods per plant (6.42), number of seeds per pod (10.90), minimum pod length $(16.98 \mathrm{~cm})$ and 1000 -seed weight $(63.02 \mathrm{~g})$.The results revealed that higher soil water availability as a result of higher level of irrigation $\left(\mathrm{I}_{3}\right)$ on regular basis increased the growth and yield contributing parameters, while imposition of moderate $\left(\mathrm{I}_{2}\right)$ or higher deficit irrigation $\left(\mathrm{I}_{1}\right)$ had significantly negative or adverse effects on plant growth and yield variables due to soil water stress. Adequate soil water availability might have enhanced the water and nutrients absorption as a result of increasing root growth and proliferation due to greater root zone aeration, increasing microbial activities and many biochemical and enzymatic reactions in soil, more production of photosynthates and its translocation in different plant parts which eventually hastened the growth and yield attributes and nodulation of crop. The beneficial effect of irrigation application at two critical stages i.e., at branching stage and pod development stage of crop on the improvement of growth and yield attributes was reported earlier by Game et al., (2014) ${ }^{(9)}$ and Rajemahadiket al., $(2018)^{(14)}$.

As regards to nutrient management, the addition of $100 \%$ RDF $\left(\mathrm{F}_{4}\right)$ recorded the maximum plant height $(85.25 \mathrm{~cm})$, number of nodules per plant (41.95), number of branches per plant (5.74), number of pods per plant (10.60), number of seeds per pod (13.95), pod length $(18.37 \mathrm{~cm})$ and 1000-seed weight $(69.79 \mathrm{~g})$ which were significantly superior to the remaining organic nutrient treatments. The next higher growth and yield variables were recorded with cowdung manure $\left(\mathrm{F}_{2}\right)$, poultry manure $\left(\mathrm{F}_{3}\right)$ and $\mathrm{FYM}\left(\mathrm{F}_{1}\right)$ in descending order, respectively. The least growth and plant variables were obtained with the treatment receiving no chemical fertilizers and organic manures. The findings amply suggest that application of inorganic NPK fertilizers might have guaranteed the optimum availability of nutrients in soil which in turn encouraged the plant to be more photosynthetically active for increasing vegetative growth and yield contributing characters. On the other hand, application of various organic substrates having slow nutrients releasing characteristics was not sufficient enough to meet the plant nutrition at all growth stages resulting in moderate 
growth and yield contributing parameters. The obtained results are in agreement with the findings of Game et al., (2014) ${ }^{(9)}$.

The interaction effects between irrigation and nutrient management showed that tallest plant height $(88.11 \mathrm{~cm})$ and maximum number of nodules per plant (44.36), number of branches per plant (7.39), number of pods per plant (12.41), number of seeds per pod (15.09), pod length $(19.14 \mathrm{~cm})$ and 1000-seed weight $(72.27 \mathrm{~g})$ were found with irrigation schedule at $\mathrm{CPE} 40$ coupling with $100 \% \mathrm{RDF}\left(\mathrm{I}_{3} \mathrm{~F}_{4}\right)$ which were superior to the remaining treatment combinations excepting the number of seeds per pod and pod length where the interaction effects were non-significant. This was ascribed to the higher availability and absorption of water and nutrients by plant throughout the growth stages as a result of recommended dose of fertilizers application under the optimum irrigation regime. Low nutrients supply from organic inputs under soil moisture stress as a consequence of deficit level of irrigation application might have resulted declined growth and plant parameters. The lowest growth and plant attributes were recorded with deficit irrigation at CPE 60 without manuring and fertilization $\left(\mathrm{I}_{1} \mathrm{~F}_{0}\right)$.

\section{Green pod and seed yield}

Application of differential irrigation regimes and inorganic and organic nutrients had significant variations on green pod yield and seed yield of cowpea (Table 3). Among the variable irrigation levels, highest green pod yield (41.36 q/ha) and seed yield (11.36 q/ha) was recorded from irrigation at CPE 40 which was statistically superior to moderate deficit irrigation at CPE 50 and higher deficit irrigation at CPE 60 with the corresponding values of $40.50 \mathrm{q} / \mathrm{ha}$ and $10.74 \mathrm{q} / \mathrm{ha}$ and 39.11 $\mathrm{q} / \mathrm{ha}$ and $10.24 \mathrm{q} / \mathrm{ha}$, respectively. It is conspicuous that deficit irrigation regimes might have failed to mitigate the plant water requirement possibly due to high soil water stress which restricts transpiration, stomatal opening and reduced ${ }^{14} \mathrm{CO}_{2}$ fixation resulting in low photosynthetic activity and retarded growth and expansion of leaf area and eventually depressed the pod and seed yield (Nemeskéri and Helyes, 2019) ${ }^{(12}$ ). This amply indicates that maintenance of no soil water stress with optimum irrigation supply all through the growth stages is imperative in increasing the yield, probably due to better water and nutrient distribution and utilization by plant and excellent soil-water-air relationship with higher oxygen concentration in the root zone (Acar et al., 2008) ${ }^{(3)}$.

Similarly, application of $100 \%$ RDF $\left(\mathrm{F}_{4}\right)$ displayed maximum green pod yield (44.20 q/ha) and seed yield (12.83 q/ha) which were significantly superior over the remaining organic nutrient treatments. Subsequent higher yields were found with cowdung manure $\left(\mathrm{F}_{2}\right)$, poultry manure $\left(\mathrm{F}_{3}\right)$ and $\mathrm{FYM}$ $\left(\mathrm{F}_{1}\right)$ in decreasing order, respectively. The lowest yields were obtained with the control treatment receiving no inorganic and organic fertilizers. The results indicate that ready supply of macronutrients through recommended chemical fertilizers might have assured optimum nutrients availability in soil which in effect promoted carbohydrate synthesis by photosynthesis, increases assimilate production and ultimately allocation to seed that increased the size and weight of pod and enhanced seed yield (Tsegaye et al., 2016) ${ }^{(19)}$. Contrary to this, the different organic components having slow nutrients releasing characteristics were not adequate sufficient to satisfy the plant nutrition demand at all growth stages resulting in moderate yields. These results are in harmony with the findings of Rajemahadik et al., (2018) ${ }^{(14)}$ that $100 \%$ RDF below seed placement recorded significantly the higher grain yield. 
The interaction effect between irrigation regimes and nutrient management on pod and seed yield was not statistically significant (Table 3). However, maximum pod yield (45.61 q/ha) and seed yield (13.62 q/ha) was registered with the treatment combination of irrigation schedule at CPE 40 with $100 \%$ RDF $\left(\mathrm{I}_{3} \mathrm{~F}_{4}\right)$ which was followed immediately by irrigation at CPE 50 with $100 \% \mathrm{RDF}\left(\mathrm{I}_{3} \mathrm{~F}_{2}\right)$ and irrigation at CPE 40 with cowdung manure $\left(\mathrm{I}_{3} \mathrm{~F}_{2}\right)$ with the corresponding values of 44.41 and $12.63 \mathrm{q} / \mathrm{ha}$ and 43.31 and 12.79 q/ha, respectively. However, under water constraint, deficit irrigation schedule at $\mathrm{CPE}$ 60 in association with $100 \% \operatorname{RDF}\left(\mathrm{I}_{1} \mathrm{~F}_{4}\right)$ was the alternative option recording relatively moderate pod and seed yield. Minimum pod yield (35.12 q/ha) and seed yield (7.50 q/ha) was recorded with deficit irrigation at CPE 60 without nutrient addition $\left(\mathrm{I}_{1} \mathrm{~F}_{0}\right)$. Higher water availability under favourable irrigation regime complemented with readily available chemical fertilizers might have facilitated better water and nutrient use by plant resulting in higher yield. Conversely, deficit irrigation regime without addition of nutrients rendered a harmful effect on yield reduction. The results corroborated with the observations of Game et al., (2014) ${ }^{(9)}$ who reported the non-significant relationship between irrigation and fertilizer on pod yield in cowpea.

\section{Seasonal crop water use and crop water use efficiency}

The different components of soil water balance during the cropping period under different irrigation regimes and nutrition are presented in Table 4. The depth of water applied under irrigation scheduling at CPE 60 $\mathrm{mm}\left(\mathrm{I}_{1}\right), \mathrm{CPE} 50 \mathrm{~mm}\left(\mathrm{I}_{2}\right)$ and $\mathrm{CPE} 40 \mathrm{~mm}\left(\mathrm{I}_{3}\right)$ was 50, 100 and $150 \mathrm{~mm}$, respectively.

The effective rainfall during the experimental period was $38.5 \mathrm{~mm}$, whereas the soil profile contribution ranged from 20.8 to $25.4 \mathrm{~mm}$. Thus the seasonal crop water use or, actual crop evapotranspiration (ETa) under irrigation scheduling of $\mathrm{I}_{1}, \mathrm{I}_{2}$ and $\mathrm{I}_{3}$ was $112.0,161.4$ and $210.6 \mathrm{~mm}$, respectively.

Table.1 Physical and hydro-physical properties of the experimental soil

\begin{tabular}{|c|c|c|c|c|c|c|c|c|}
\hline \multirow{2}{*}{$\begin{array}{c}\text { Soil } \\
\text { depth } \\
(\mathrm{cm})\end{array}$} & \multicolumn{3}{|c|}{ Soil texture $(\%)$} & \multirow{2}{*}{$\begin{array}{c}\text { BD } \\
\left(\mathrm{Mg} / \mathrm{m}^{3}\right)\end{array}$} & \multirow{2}{*}{$\begin{array}{c}\text { Ks } \\
(\mathrm{cm} / \mathbf{h r})\end{array}$} & \multirow{2}{*}{$\begin{array}{c}\text { Infiltration } \\
(\mathrm{cm} / \mathrm{hr})\end{array}$} & \multirow{2}{*}{$\begin{array}{l}\text { FC } \\
(\%, \\
\text { v/v) }\end{array}$} & \multirow{2}{*}{$\begin{array}{c}\text { PWP } \\
(\%, \\
\mathbf{v} / \mathbf{v})\end{array}$} \\
\hline & Sand & Silt & Clay & & & & & \\
\hline $0-15$ & 38.65 & 26.10 & 35.25 & 1.47 & 2.41 & 1.53 & 31.21 & 17.85 \\
\hline $15-30$ & 40.18 & 27.24 & 32.58 & 1.51 & 2.28 & 1.38 & 30.61 & 17.09 \\
\hline $30-45$ & 43.23 & 24.65 & 30.12 & 1.56 & 2.19 & 1.24 & 30.61 & 16.47 \\
\hline
\end{tabular}

FC: field capacity, PWP: permanent wilting point, BD: bulk density, Ks: hydraulic conductivity

Table2 Chemical properties of the experimental soil

\begin{tabular}{|c|c|c|c|c|c|c|}
\hline $\begin{array}{c}\text { Soil depth } \\
(\mathbf{c m})\end{array}$ & $\begin{array}{c}\mathbf{p}^{\mathbf{H}} \\
(\mathbf{1 : 2 . 5})\end{array}$ & $\begin{array}{c}\mathbf{E C} \\
(\mathbf{d S} / \mathbf{m})\end{array}$ & $\begin{array}{c}\text { Organic C } \\
(\mathbf{g} / \mathbf{k g})\end{array}$ & $\begin{array}{c}\text { Available N } \\
(\mathbf{k g} / \mathbf{h a})\end{array}$ & $\begin{array}{c}\text { Available } \\
\mathbf{P}(\mathbf{k g} / \mathbf{h a})\end{array}$ & $\begin{array}{c}\text { Available K } \\
\text { ( kg/ha) }\end{array}$ \\
\hline $\mathbf{0 - 1 5}$ & 6.73 & 0.18 & 6.17 & 198.5 & 29.8 & $\mathbf{1 4 6 . 9}$ \\
\hline $\mathbf{1 5 - 3 0}$ & 6.68 & 0.16 & 5.34 & 174.5 & 34.3 & $\mathbf{1 3 8 . 5}$ \\
\hline $\mathbf{3 0 - 4 5}$ & $\mathbf{6 . 4 2}$ & $\mathbf{0 . 1 5}$ & $\mathbf{4 . 4 6}$ & $\mathbf{1 6 3 . 3}$ & $\mathbf{2 8 . 4}$ & $\mathbf{1 2 6 . 7}$ \\
\hline
\end{tabular}


Table.3 Effect of varying levels of irrigation and nutrition on growth, yield attributes and yield of summer cowpea during 2018

\begin{tabular}{|c|c|c|c|c|c|c|c|c|c|c|c|c|c|c|c|c|c|c|}
\hline $\begin{array}{c}\text { Treatme } \\
\text { nt }\end{array}$ & \multicolumn{2}{|c|}{$\begin{array}{c}\text { Plant } \\
\text { height } \\
(\mathrm{cm})\end{array}$} & \multicolumn{2}{|c|}{$\begin{array}{c}\text { No of } \\
\text { nodules/ } \\
\text { plant }\end{array}$} & \multicolumn{2}{|c|}{$\begin{array}{c}\text { No of } \\
\text { branches/ } \\
\text { plant }\end{array}$} & \multicolumn{2}{|c|}{$\begin{array}{l}\text { No of } \\
\text { pods/ } \\
\text { Plant }\end{array}$} & \multicolumn{2}{|c|}{$\begin{array}{l}\text { No of } \\
\text { seed/ } \\
\text { pod }\end{array}$} & \multicolumn{2}{|c|}{$\begin{array}{l}\text { Pod } \\
\text { length } \\
(\mathrm{cm})\end{array}$} & \multicolumn{2}{|c|}{$\begin{array}{l}1000 \text { seed } \\
\text { weight } \\
\text { (g) }\end{array}$} & \multicolumn{2}{|c|}{$\begin{array}{c}\text { Green } \\
\text { pod yield } \\
\text { (q/ha) }\end{array}$} & \multicolumn{2}{|c|}{$\begin{array}{l}\text { Seed } \\
\text { yield } \\
\text { (q/ha) }\end{array}$} \\
\hline \multicolumn{19}{|c|}{ Irrigation (I) } \\
\hline $\mathbf{I}_{1}$ & \multicolumn{2}{|c|}{72.27} & \multicolumn{2}{|c|}{32.87} & \multicolumn{2}{|c|}{3.54} & \multicolumn{2}{|c|}{6.42} & \multicolumn{2}{|c|}{10.9} & \multicolumn{2}{|c|}{16.98} & \multicolumn{2}{|c|}{63.02} & \multicolumn{2}{|c|}{39.11} & \multicolumn{2}{|c|}{10.24} \\
\hline $\mathbf{I}_{2}$ & \multicolumn{2}{|c|}{74.7} & \multicolumn{2}{|c|}{34.84} & \multicolumn{2}{|c|}{4.98} & \multicolumn{2}{|c|}{8.44} & & 03 & & & & 08 & & .5 & & 74 \\
\hline $\mathbf{I}_{3}$ & & 38 & & 08 & & & & 61 & & & & & & 62 & & & & 36 \\
\hline $\operatorname{SEm}( \pm)$ & & 19 & & & & & & 07 & & & & & & 14 & & 13 & & 33 \\
\hline $\begin{array}{c}\text { CD } \\
(0.05)\end{array}$ & & 75 & & & & & & 31 & & & & & & 58 & & 56 & & 15 \\
\hline Nutrition & & & & & & & & & & & & & & & & & & \\
\hline $\mathbf{F}_{\mathbf{0}}$ & & 89 & & & & & & 22 & & 57 & & & & 42 & & 12 & & 55 \\
\hline $\mathbf{F}_{1}$ & & 65 & & 94 & & & & 56 & & & & & & 99 & & 92 & & 59 \\
\hline $\mathbf{F}_{2}$ & & 58 & & 15 & & & & 85 & & 16 & & & & 32 & & 14 & & 14 \\
\hline $\mathbf{F}_{3}$ & & 54 & & 91 & & & & 23 & & & & & & 36 & & 24 & & 28 \\
\hline $\mathbf{F}_{4}$ & & 25 & & 95 & & & & .6 & & 95 & & & & 79 & & .2 & & 83 \\
\hline $\operatorname{SEm}( \pm)$ & & 18 & & & & & & 21 & & & & & & 22 & & 21 & & 16 \\
\hline $\begin{array}{c}\text { CD } \\
(\mathbf{0 . 0 5})\end{array}$ & & 54 & & & & & & 63 & & & & & & 67 & & 53 & & 47 \\
\hline Interacti & $(\mathbf{I} \mathbf{x}$ & & & & & & & & & & & & & & & & & \\
\hline $\mathbf{I}_{1} \mathbf{F}_{0}$ & & 56 & & 56 & & & & & & & & & & 1 & & & & 50 \\
\hline $\mathbf{I}_{1} \mathbf{F}_{1}$ & & 10 & & & & & & & & 70 & & & & 22 & & 08 & & 39 \\
\hline $\mathbf{I}_{1} \mathbf{F}_{2}$ & & 61 & & 66 & & & & 43 & & & & & & 51 & & 04 & & 60 \\
\hline $\mathbf{I}_{1} \mathbf{F}_{3}$ & & 18 & & & & & & 3 & & 56 & & & & 64 & & & & 96 \\
\hline $\mathbf{I}_{1} \mathbf{F}_{4}$ & & 95 & & & & & & & & & & & & 65 & & 57 & & 24 \\
\hline $\mathbf{I}_{2} \mathbf{F}_{0}$ & & 52 & & 10 & & & & & & & & & & 60 & & 08 & & 10 \\
\hline $\mathbf{I}_{2} \mathbf{F}_{1}$ & & 09 & & 76 & & & & 49 & & & & & & 17 & & 21 & & 74 \\
\hline $\mathbf{I}_{2} \mathbf{F}_{2}$ & & 46 & & 12 & & & & 86 & & 22 & & & & 38 & & 05 & & 04 \\
\hline $\mathbf{I}_{2} \mathbf{F}_{3}$ & & 70 & & 44 & & & & 33 & & & & & & 83 & & 74 & & 19 \\
\hline $\mathbf{I}_{2} \mathbf{F}_{4}$ & & 71 & & 80 & & & & 37 & & 60 & & & & 44 & & 41 & & 63 \\
\hline $\mathbf{I}_{3} \mathbf{F}_{0}$ & & 61 & & & & & & 84 & & 85 & & & & 58 & & 17 & & 57 \\
\hline $\mathbf{I}_{3} \mathbf{F}_{1}$ & & 77 & & 33 & & & & 92 & & & & & & 59 & & 48 & & 14 \\
\hline $\mathbf{I}_{3} \mathbf{F}_{2}$ & & 69 & & 66 & & & & 25 & & & & & & 08 & & 31 & & 79 \\
\hline $\mathbf{I}_{3} \mathbf{F}_{3}$ & & 74 & & 60 & & & & 64 & & 90 & & & & 61 & & 23 & & 68 \\
\hline $\mathbf{I}_{3} \mathbf{F}_{4}$ & & 11 & & 36 & & & & 41 & & & & 14 & & 27 & & 61 & & 62 \\
\hline & $\begin{array}{l}\text { (Ix } \\
\text { F) }\end{array}$ & $\begin{array}{l}\text { (Fx } \\
\text { I) }\end{array}$ & $\begin{array}{l}\text { (Ix } \\
\mathrm{F})\end{array}$ & $\begin{array}{l}(\mathrm{F} \times \\
\mathrm{I})\end{array}$ & $\begin{array}{l}\text { (Ix } \\
\text { F) }\end{array}$ & $\begin{array}{c}(\mathrm{F} \times \mathrm{I} \\
)^{2}\end{array}$ & $\begin{array}{l}\text { (Ix } \\
\text { F) }\end{array}$ & $\begin{array}{l}(\mathrm{F} \times \\
\mathrm{I})\end{array}$ & $\begin{array}{l}\text { (Ix } \\
\text { F) }\end{array}$ & $\begin{array}{l}(\mathrm{F} \times \\
\mathrm{I})\end{array}$ & $\begin{array}{l}\text { (IX } \\
\text { F) }\end{array}$ & $\begin{array}{l}(\mathrm{F} \times \\
\mathrm{I})\end{array}$ & $\begin{array}{l}\text { (Ix } \\
\mathrm{F})\end{array}$ & $(\mathrm{F} \times \mathrm{I})$ & $\begin{array}{l}\text { (Ix } \\
\text { F) }\end{array}$ & $\begin{array}{l}(\mathrm{Fx} \\
\mathrm{I})\end{array}$ & $\begin{array}{l}\text { (Ix } \\
\mathrm{F})\end{array}$ & $\begin{array}{l}(\mathrm{F} \times \\
\mathrm{I})\end{array}$ \\
\hline $\operatorname{SEm}( \pm)$ & $\begin{array}{c}0.3 \\
4\end{array}$ & $\begin{array}{c}0.4 \\
1\end{array}$ & $\begin{array}{c}0.2 \\
8\end{array}$ & $\begin{array}{c}0.2 \\
9\end{array}$ & $\begin{array}{c}0.2 \\
0\end{array}$ & 0.25 & $\begin{array}{c}0.3 \\
4\end{array}$ & $\begin{array}{c}0.1 \\
7\end{array}$ & $\begin{array}{c}0.3 \\
9\end{array}$ & $\begin{array}{c}0.1 \\
8\end{array}$ & 0.3 & $\begin{array}{c}0.3 \\
1\end{array}$ & $\begin{array}{c}0.3 \\
8\end{array}$ & 0.32 & $\begin{array}{c}0.3 \\
6\end{array}$ & $\begin{array}{c}0.3 \\
1\end{array}$ & $\begin{array}{c}0.2 \\
5\end{array}$ & $\begin{array}{c}0.0 \\
8\end{array}$ \\
\hline $\begin{array}{c}\text { CD } \\
(0.05)\end{array}$ & $\begin{array}{c}1.1 \\
1\end{array}$ & $\begin{array}{c}1.0 \\
4\end{array}$ & $\begin{array}{c}0.9 \\
0\end{array}$ & $\begin{array}{c}0.8 \\
9\end{array}$ & $\begin{array}{c}0.6 \\
7\end{array}$ & 0.62 & NS & NS & $\begin{array}{c}1.1 \\
7\end{array}$ & $\begin{array}{c}1.2 \\
8\end{array}$ & NS & NS & $\begin{array}{c}1.1 \\
8\end{array}$ & 1.22 & NS & NS & NS & NS \\
\hline
\end{tabular}

$\mathrm{I}_{1}$ : CPE $60 \mathrm{~mm}, \mathrm{I}_{2}$ : CPE $50 \mathrm{~mm}, \mathrm{I}_{3}:$ CPE $40 \mathrm{~mm} ; \mathrm{F}_{0}$ : Control, $\mathrm{F}_{1}: \mathrm{FYM}, \mathrm{F}_{2}$ : Cowdung, $\mathrm{F}_{3}:$ Poultry manure, $\mathrm{F}_{4}: \mathrm{RDF}$ 
Table.4 Soil water balance components, actual crop evapotranspiration (ETa) and crop water use efficiency (CWUE) of summer cowpea during 2018

\begin{tabular}{|c|c|c|c|c|c|}
\hline $\begin{array}{c}\text { Treatment } \\
(\mathbf{I} \times \mathbf{F})\end{array}$ & $\begin{array}{c}\text { Irrigation } \\
\text { water }(\mathbf{m m})\end{array}$ & $\begin{array}{c}\text { Effective } \\
\text { rainfall }(\mathbf{m m})\end{array}$ & $\begin{array}{c}\text { Profile moisture } \\
\text { contribution }(\mathbf{m m})\end{array}$ & $\begin{array}{c}\text { ETa } \\
(\mathbf{m m})\end{array}$ & $\begin{array}{c}\text { CWUE } \\
(\mathbf{k g} / \mathbf{h a - m m})\end{array}$ \\
\hline $\mathbf{I}_{\mathbf{1}} \mathbf{F}_{\mathbf{0}}$ & 50 & 38.5 & 22.4 & 110.9 & 6.76 \\
\hline $\mathbf{I}_{\mathbf{1}} \mathbf{F}_{\mathbf{1}}$ & 50 & 38.5 & 22.6 & 111.1 & 8.00 \\
\hline $\mathbf{I}_{\mathbf{1}} \mathbf{F}_{\mathbf{2}}$ & 50 & 38.5 & 23.1 & 111.6 & 10.39 \\
\hline $\mathbf{I}_{\mathbf{1}} \mathbf{F}_{\mathbf{3}}$ & 50 & 38.5 & 24.2 & 112.7 & 9.72 \\
\hline $\mathbf{I}_{\mathbf{1}} \mathbf{F}_{\mathbf{4}}$ & 50 & 38.5 & 25.4 & 113.9 & 10.75 \\
\hline $\mathbf{I}_{\mathbf{2}} \mathbf{F}_{\mathbf{0}}$ & 100 & 38.5 & 21.9 & 160.4 & 5.05 \\
\hline $\mathbf{I}_{\mathbf{2}} \mathbf{F}_{\mathbf{1}}$ & 100 & 38.5 & 21.6 & 160.1 & 6.08 \\
\hline $\mathbf{I}_{\mathbf{2}} \mathbf{F}_{\mathbf{2}}$ & 100 & 38.5 & 22.9 & 161.4 & 7.46 \\
\hline $\mathbf{I}_{\mathbf{2}} \mathbf{F}_{\mathbf{3}}$ & 100 & 38.5 & 23.7 & 162.2 & 6.90 \\
\hline $\mathbf{I}_{\mathbf{2}} \mathbf{F}_{\mathbf{4}}$ & 100 & 38.5 & 24.5 & 163 & 7.75 \\
\hline $\mathbf{I}_{\mathbf{3}} \mathbf{F}_{\mathbf{0}}$ & 150 & 38.5 & 21.2 & 209.7 & 4.09 \\
\hline $\mathbf{I}_{\mathbf{3}} \mathbf{F}_{\mathbf{1}}$ & 150 & 38.5 & 20.8 & 209.3 & 4.84 \\
\hline $\mathbf{I}_{\mathbf{3}} \mathbf{F}_{\mathbf{2}}$ & 150 & 38.5 & 21.9 & 210.4 & 6.08 \\
\hline $\mathbf{I}_{\mathbf{3}} \mathbf{F}_{\mathbf{3}}$ & 150 & 38.5 & 22.6 & 211.1 & 5.53 \\
\hline $\mathbf{I}_{\mathbf{3}} \mathbf{F}_{\mathbf{4}}$ & 150 & 38.5 & 24 & 212.5 & 6.41 \\
\hline
\end{tabular}

$\mathrm{I}_{1}$ : CPE $60 \mathrm{~mm}, \mathrm{I}_{2}$ : CPE $50 \mathrm{~mm}, \mathrm{I}_{3}:$ CPE $40 \mathrm{~mm} ; \mathrm{F}_{0}$ : Control, $\mathrm{F}_{1}$ : FYM, $\mathrm{F}_{2}$ : Cowdung, $\mathrm{F}_{3}$ : Poultry manure, $\mathrm{F}_{4}$ : RDF

Table.5 Relationship between the decrease in relative water use and decrease in relative yield for cowpea

\begin{tabular}{|c|c|c|c|c|c|c|c|}
\hline $\begin{array}{c}\text { Irrigation } \\
\text { schedule }\end{array}$ & $\begin{array}{c}\text { ETa } \\
(\mathbf{m m})\end{array}$ & $\begin{array}{c}\mathbf{E T m} \\
\mathbf{( m m})\end{array}$ & $\mathbf{( 1 - E T a / E T m )}$ & $\begin{array}{c}\mathbf{Y a} \\
\mathbf{( k g / h a})\end{array}$ & $\begin{array}{c}\mathbf{Y m} \\
(\mathbf{k g} / \mathbf{h a})\end{array}$ & $\mathbf{( 1 - Y a / Y m )}$ & $\mathbf{K y}$ \\
\hline CPE 40 & 210.60 & 210.60 & 0.000 & 1136 & 1136 & 0.000 & 0 \\
\hline CPE 50 & 161.42 & 210.60 & 0.234 & 1074 & 1136 & 0.055 & 0.234 \\
\hline CPE 60 & 112.04 & 210.60 & 0.468 & 1024 & 1136 & 0.099 & 0.211 \\
\hline
\end{tabular}

$\mathrm{I}_{1}: \mathrm{CPE} 60 \mathrm{~mm}, \mathrm{I}_{2}:$ CPE $50 \mathrm{~mm}, \mathrm{I}_{3}: \mathrm{CPE} 40 \mathrm{~mm}$

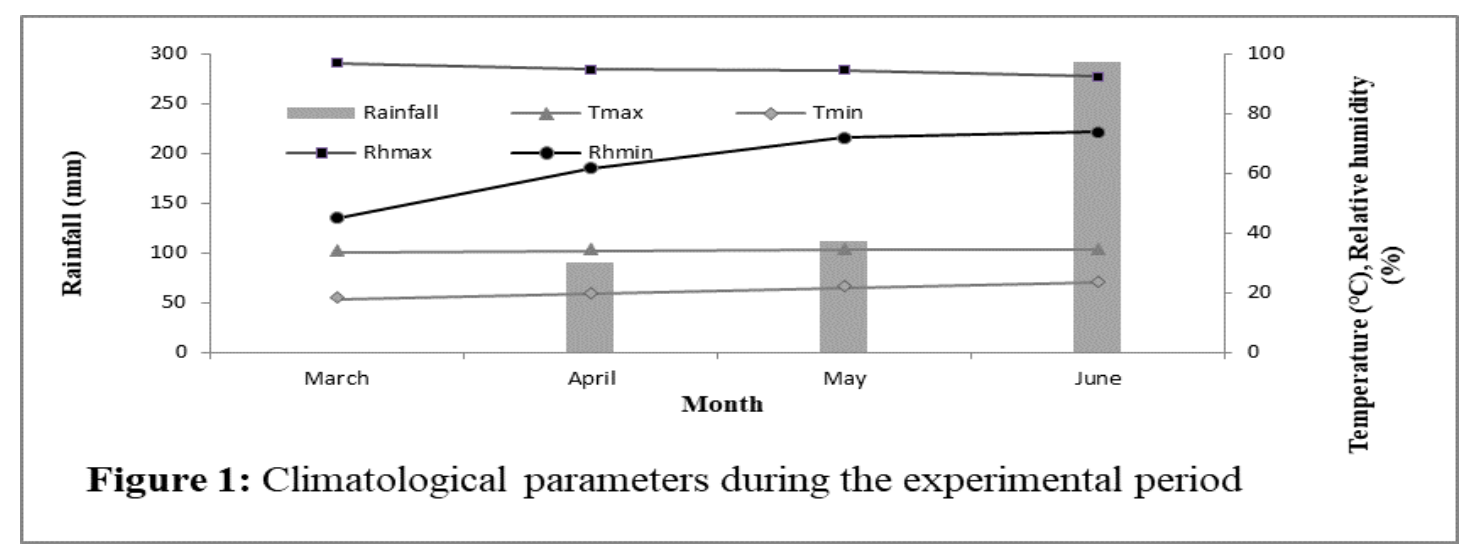



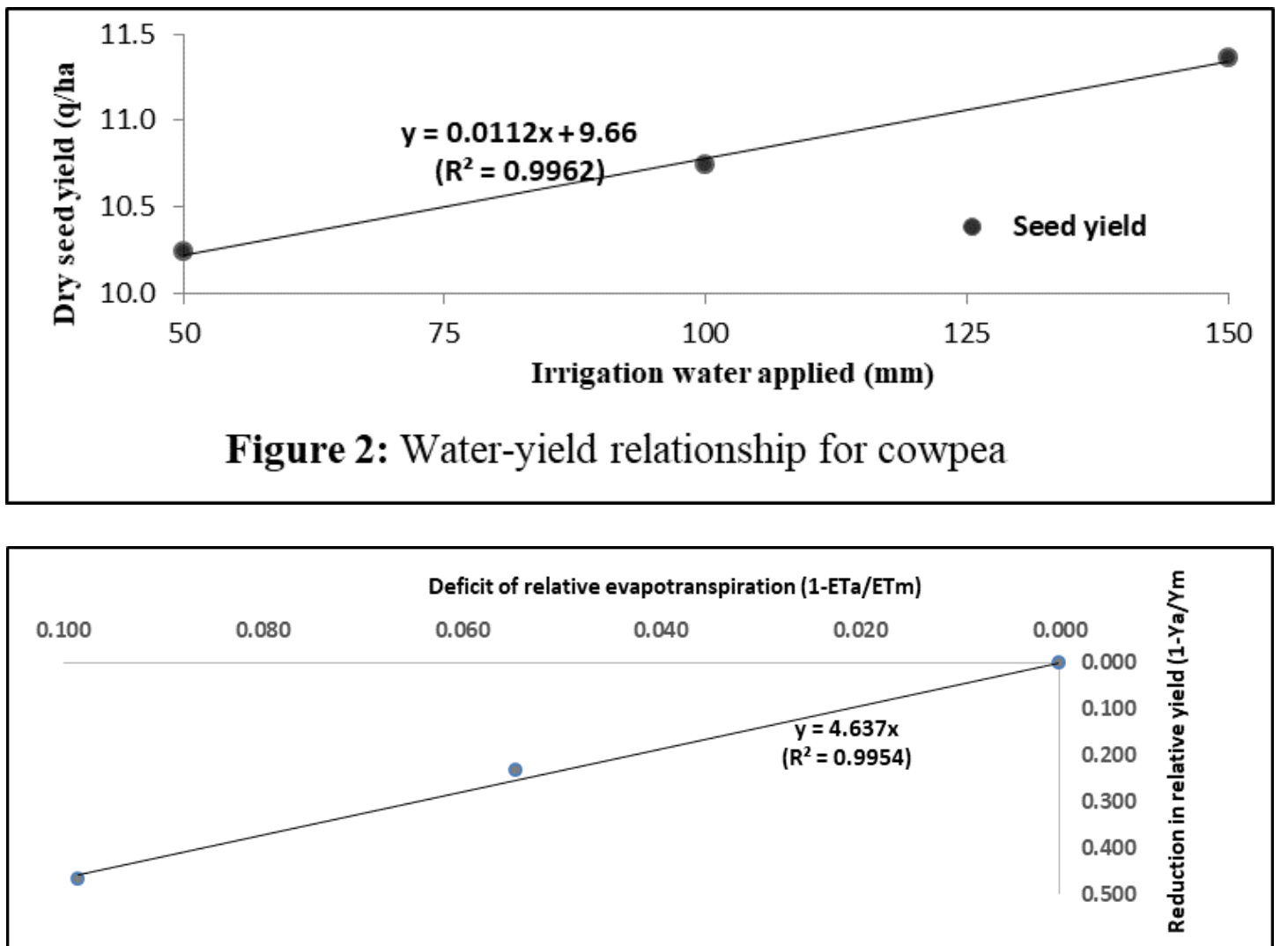

Figure 3: Relationship between relative yield deficit and relative evapotranspiration deficit

The results indicate that maximum crop water use efficiency (CWUE) of $10.75 \mathrm{~kg} / \mathrm{ha}-\mathrm{mm}$ was obtained with irrigation scheduling at CPE 60 coupling with $\mathrm{RDF}\left(\mathrm{I}_{1} \mathrm{~F}_{4}\right)$ which was followed by irrigation at CPE 60 along with cowdung $\left(\mathrm{I}_{1} \mathrm{~F}_{2}\right)$ as $10.39 \mathrm{~kg} / \mathrm{ha}-\mathrm{mm}$ and CPE 60 with poultry manure $\left(\mathrm{I}_{1} \mathrm{~F}_{3}\right)$ as $9.72 \mathrm{~kg} / \mathrm{ha}-$ $\mathrm{mm}$. Minimum WUE of $4.09 \mathrm{~kg} / \mathrm{ha}-\mathrm{mm}$ was recorded with irrigation scheduling at CPE 40 without nutrition $\left(\mathrm{I}_{3} \mathrm{~F}_{0}\right)$. This indicates that the crop imposed under higher deficit irrigation schedule at CPE 60 in conjunction with recommended dose of mineral fertilizers or, poultry manure might have used all irrigation water applied for production function resulting in higher crop water use efficiency.

\section{Crop yield - water production function}

The relationship between cowpea seed yield (y) and the quantity of irrigation water applied (x) was computed by regression analysis. Seed yield was taken as dependent variable and plotted against ' $x$ ' to derive $a$ mathematical function (Figure 2). A strong linear relationship was best fitted between $\mathrm{y}$ and $x$ as, $y=0.0112 x+9.66\left(R^{2}=0.996\right)$

The graph indicates that the increase in seed yield was proportional to the increase in water application. This model approach can successfully be used for predicting yield under different irrigation water supply. The highest reduction in seed yield was observed with deficit irrigation at CPE 60 (9.9\%) followed by CPE 50 (5.5\%) as against optimum irrigation at CPE 40 which might have resulted more negative effect on crop through higher soil water deficit. This predictive model can also serve as a good guideline for cowpea growers in the lower Indo-Gangetic plains region to yield potential 
allocation decision related to varying water supply condition. The above results is in line with the observations of Bozkurt et al., (2011) ${ }^{(5)}$ who found significant linear relationship between crop yield-water production function for hybrid corn in eastern Mediterranean climatic condition, especially in the deficit irrigation range, because all the applied water was used by crop.

\section{Crop yield response factor $(\mathrm{Ky})$}

The response of seed yield of cowpea to water use during growing season is quantified through the yield response factor $\left({ }^{K y}\right)$ and was computed using the equation given by Doorenbos and Kassam (1979) ${ }^{(8)}$ as

$\mathrm{Ky}=\frac{1-\mathrm{Ya} / \mathrm{Ym}}{1-\mathrm{ETa} / \mathrm{ETm}}$

Where, Ya is the actual seed yield ( $\mathrm{kg} / \mathrm{ha})$, $\mathrm{Ym}$ is the maximum seed yield ( $\mathrm{kg} / \mathrm{ha})$, ETa is the actual evapotranspiration ( $\mathrm{mm}$ ) and ETm is the maximum evapotranspiration $(\mathrm{mm})$ and $\mathrm{Ky}$ is the response factor to deficit irrigation. $\mathrm{Ky}$ is the slope of the linear relationship between the reduction in relative yield and the reduction in relative evapotranspiration. It shows the response of yield with concomitant decrease in water consumption. In other words, it explains the decline in seed yield with respect to per unit decrease in water use. The relationship between relative yield deficit and relative evapotranspiration deficit for cowpea is furnished in Figure 3. The seasonal yield response factor (Ky) was found to be 4.64 with high coefficient of determination $\left(\mathrm{R}^{2}=\right.$ 0.99). The value of Ky increased first with increase in water deficit and then marginally decreased with further increase in water deficit (Table 5). This reveals to the fact that the yield decrease was not proportional to the higher degree of water stress. The higher seasonal Ky value under water stress condition indicates that the plant will have a greater yield loss when the optimal crop water requirements are not fulfilled. This also implies a high impact of soil water stress condition on the seed yield. According to the proposition of Doorenbos and Kassam (1979) (8) that if $\mathrm{Ky}>1.0$, the reduction in yield is proportionally larger with decrease in water use as the crop is very sensitive to soil water deficit. Thus maintenance of optimum soil water regime by proper irrigation scheduling based CPE at all growth stages of cowpea is very imperative.

In conclusion, the under plenty or assured water supply condition, scheduling of irrigation at CPE 40 accompanied with $100 \%$ recommended dose of fertilizers (12.5:25:12.5 $\mathrm{kg} / \mathrm{ha}$ of $\mathrm{N}, \mathrm{P}$ and $\mathrm{K}$, respectively) as basal was found to be the best treatment combination for obtaining maximum growth, yield components, pod and seed yield and moderate crop water use efficiency of summer cowpea. Under water constraint, deficit irrigation schedule at CPE 60 complemented with $100 \%$ RDF was the alternative option furnishing relatively higher pod and seed yield and maximum water use efficiency of the crop grown in the lower Indo-Gangetic plains of West Bengal.

\section{References}

Abedi T, Alemzadeh A, Kazemeini SA. Wheat yield and grain protein response to nitrogen amount and timing. Australian Journal of Crop Science. 2011; 5:330-336.

Aboamera MA. Response of cowpea to water deficit under semi-portable sprinkler irrigation system. Misr Journal of Agricultural Engineering. 2010; 27(1):170-190.

Acar, B,Paksoy M, Turkmen O, Seymen M. Irrigation and nitrogen level affect lettuce yield in greenhouse condition. 
African Journal of Biotechnology. 2008; 7(24):4450-4453.

Arul Prakasham SM, Ramanathan SP, Annadurai K, JeberlinPrabina B. Influence of irrigation regimes and organics on the productivity and quality of vegetable cowpea (Vigna unguiculata (L.) Walp). Journal of Pharmacognosy and Phytochemistry. 2019; 8(3):3391-3393.

Bozkurt S, Yazar A, Mansuroglu GS. Effects of different drip irrigation levels on yield and some agronomic characteristics of raised bed planted corn. African Journal of Agricultural Research. 2011; 6(23):5291-5300.

Chemutai C, Cheminingwa GN, Ambuko J. Effect of fertilizers and harvesting method on yield of cowpea. African Journal of Rural Development. 2018; $3(2): 1-7$.

Daramy MA, Sarkodie-Addo J, Dumbuya G. The effects of nitrogen and phosphorus fertilizer application on crude protein, nutrient concentration and nodulation of cowpea in Ghana. ARPN Journal of Agricultural and Biological Science. 2016; 11:470-480.

Doorenbos J, Kassam AH. Yield response to water. FAO Irrigation and Drainage Paper No. 33, FAO, Rome, Italy. 1979; 193.

Game VN, Mahadkar UV, Khetre OS. Effect of irrigation and levels of fertilizers application on growth and yield of zero tilled cowpea (Vigna unguiculata L.). International Journal of Agricultural Sciences. 2014; 10(2):743-746.

Gomez KA, Gomez AA. Statistical Procedures for Agricultural Research ( $2^{\text {nd }}$ Edition). John Wiley and Sons, New York. 1984; 91-115.

Namakka A, Jibrin DM, Hamma IL, Bulus J. Effect of phosphorus levels on growth and yield of cowpea (Vigna unguiculata (L.) Walp) in Zaria, Nigeria. Journal of Dryland Agriculture. 2017; 3(1):85-93.

Nemeskeri, E. and Helyes, L. Physiological responses of selected vegetable crop species to water stress. Agronomy.2019; 9(8): 447.

Onuh MO, Donald KM. Effect of water stress on the rooting, nodulation potentials and growth of cowpea (Vigna unguiculata (L.) Walp). Science World Journal. 2009; 4(3):31-34.

Rajemahadik VA, Shetye VN, Chavan VG, Chavan SA, Mahadkar UV. Irrigation and fertilizer management in cowpea under zero tilled condition of south Konkan coastal zone of Maharashtra, India. International Journal of Current Microbiology and Applied Sciences. 2018; 7(12):2713-2724.

Sheahan CM. Plant guide for cowpea (Vigna unguiculata (L.) Walp). USDANatural Resources Conservation Services, Cape May, Plant Materials Center, Cape May, NJ. 2012.

Simsek M, Tonkaz T, Kacira M, Comiekcioglu N, Dogan, Z. The effects of different irrigation regimes on cucumber (Cucumbis salivus L.) yield and yield characteristics under open field conditions. Agricultural Water Management. 2005; 73:173191.

Singh A, Baoule AL, Ahmed HG, Dikko AU, Aliyu U, Sokoto MB, Alhasan J, Musa $\mathrm{M}$, Haliru. Influence of phosphorus on the performance of cowpea (Vigna unguiculata (L.) Walp) varieties in Sudan savanna of Nigeria. Journal of Agriculture Sciences. 2011a; 2:313317.

Smaling EMA, Stoorvogel JJ, Windmeijer PN. Calculating soil nutrient balances in Africa at different scales: II. District Scales. Fertility Resources. 1993; 35:237-250. 
Tsegaye B, Bizuayehu T, Woldemichael A, Mohammed A. Yield and yield components of onion (Allium cepa L.) as affected by irrigation scheduling and nitrogen fertilization at Hawassa area districts in southern Ethiopia. Journal of Medical and Biological

Science Research. 2016; 2(2):15-20. Zimmermann MJ, Rocha M, Yolanda T. Bean crop: Factors affecting productivity. Brazilian Association for the presence of potash and phosphate, Piracicaba, Brazil. 1988; 317-340.

\section{How to cite this article:}

Anirban Bhowmik, Subam Khawas, Gopal Dutta, Ratneswar Ray and Sanmoy Kr. Patra. 2020. Response of Summer Cowpea to Growth, Yield and Water Use Efficiency under Sifferent Irrigation and Nutrient Management in Lower Indo-Gangetic Plains. Int.J.Curr.Microbiol.App.Sci. 9(08): 900-911. doi: https://doi.org/10.20546/ijcmas.2020.908.098 